\title{
Urban Migration in the Later Middle Ages
}

\author{
M. Mayer
}

For citation: Mayer M. Urban Migration in the Later Middle Ages. Vestnik of Saint Petersburg University. History, 2019, vol. 64, iss. 3, pp. 980-995.

https://doi.org/10.21638/11701/spbu02.2019.310

This article deals with migration to urban centers in the late Middle Ages. Contrary to still existing popular views, medieval society was marked by a high degree of mobility in social and geographic terms. This was especially the case for urban centers. Due to a number of demographic reasons, such as low birth rates and high death rates, medieval cities depended on a constant influx of people from the outside for long-term growth and prosperity. This turns migration into one of the key phenomena to understand medieval urban society. At the same time, it is often difficult to identify migrants, especially from the lower classes of society. The sources give us only a limited number of indications of the origin and individual migration history of the urban population. This article gains insight into different forms of research into medieval urban migration history. It presents an overview of the different types of sources, the information they can provide, and the remaining problems and limitations. Tax lists or Bürgerbücher can shed light on the origins of the inhabitants of a city. Criminal registers or notary acts can help us to gain knowledge about the individual migration history of the people mentioned, and new methodologies in archaeology can provide further valuable hints. With the help of some examples from recent research, this text outlines the available options to get an insight into one of the most important phenomena of late medieval urban society. However, the problems related to dealing with urban medieval migration should not be forgotten. Information is often scarce, and our knowledge remains in many cases limited, especially, concerning lower layers of society. In addition, a certain city was only one step in a longer migration history of the individual. People often moved back and forth, bringing new ideas and techniques with them.

Keywords: Later Middle Ages, city, town, migration, demography, mobility, Social History.

Markus Mayer - PhD, Freie Universität Berlin, Friedrich-Meinecke-Institut, Koserstraße 20, 14195, Berlin, Deutschland; markus.mayer@fu-berlin.de

Маркус Майер - PhD, Свободный университет Берлина, Фридрих-Мейнеке-Институт, Германия, Берлин, 14195, Козерштрассе, 20; markus.mayer@fu-berlin.de

I would like to express my gratitude to Thomas Ertl, Alicia Lohmann, Hannah Potthoff and the participants of the DissertantInnentagung for Economic, Social and Environmental History in Vienna for valuable and important contributions to this paper, and especially Theresa Prinz and Catherine Gilbert for proofreading and helpful corrections.

Я благодарю Томаса Эртля, Алисию Ломанн, Ханну Поттофф и участников DissertantInnentagung по экономической, социальной и экологической истории в Вене за ценный и важный вклад в эту статью, а особенно Терезу Принц и Кэтрин Гилберт - за чтение корректуры и полезные исправления.

() Санкт-Петербургский государственный университет, 2019 


\title{
Миграция городского населения в Позднем средневековье
}

\author{
M. Maŭep
}

Для цитирования: Mayer M. Urban Migration in the Later Middle Ages // Вестник СанктПетербургского университета. История. 2019. Т. 64. Вып. 3. С.980-995.

https://doi.org/10.21638/11701/spbu02.2019.310

Статья посвящена миграции в городские центры в Позднем Средневековье. Средневековое общество, в отличие от все еще существующих популярных взглядов на него, характеризовалось высокой степенью мобильности в социальном и географическом плане. Это особенно касается городских центров. В силу ряда демографических причин, таких как низкая рождаемость и высокая смертность, средневековые города зависели от постоянного притока людей извне для устойчивого роста и процветания. Так миграция превращается в одно из ключевых явлений для понимания средневекового городского сообщества. В то же время мигрантов, особенно из низших слоев общества, зачастую трудно идентифицировать. Источники дают нам лишь ограниченное количество сведений о происхождении и индивидуальном перемещении городского населения. Данная статья дает представление о различных формах исследования истории городской миграции в период Средневековья. В ней представлен обзор различных типов источников, информации, которую они могут предоставить, а также проблем и ограничений, которые неизбежно остаются. Налоговые списки, или Bürgerbücher, могут поведать о происхождении жителей города. Регистры судимостей или нотариальные акты помогают лучше узнать историю переселения упомянутых в них лиц, а новые археологические методики дают дополнительные ценные сведения. Отталкиваясь от примеров из недавних работ, мы попытались проиллюстрировать подходы, которыми располагает исследователь, чтобы получить представление об одном из наиболее важных явлений в жизни позднесредневекового городского общества. Но не следует забывать и о проблемах, связанных со средневековой городской миграцией: из-за скудных источников наши знания во многих случаях остаются ограниченными, особенно в том, что касается более низких уровней социума. Кроме того, конкретный город мог быть лишь одним из этапов в более длительной индивидуальной истории отдельных мигрантов. Люди часто перемещались, привнося с собой новые идеи и технологии.

Ключевые слова: Позднее Средневековье, город, миграция, демография, мобильность, социальная история.

In August 1526, Conrad Resch, a printer and bookseller, sold all his books in his former house in the Grand Rue Saint-Jacques in Paris at the sum of 2466 écus d'or to his former associate Chrétien Wechel and his wife ${ }^{1}$. For Conrad Resch this was the end of two decades of constant movement. He was born in Kirchheim in Swabia not far from Stuttgart. Around 1508, he started to work for his uncle, the printer Wolfgang Lachner, in Basel. After studying at the University of Tübingen, followed by a short period of working in Lyon, he came to Paris in 1515, where he set up his own business and obtained citizenship the following year. In 1522, he inherited the shop of his uncle in Basel, also gaining citizenship there. From then on, until 1526 he regularly commuted between the two cities. His house in the Rue Saint Jacques in Paris, marked with the coat of arms of the city of Basel, the Écu de Bâle, became one of the hotspots of reformist ideas in Paris, while Con-

${ }^{1}$ Coyecque E. Recueil d'actes notariés relatifs à l'histoire de Paris et de ses environs au XVIe siècle. T. I: 1498-1545. Paris, 1905. Nr. 663. 
rad Resch - one of the main carriers of these new religious concepts from Switzerland to France and Paris ${ }^{2}$.

The individual life story of Conrad Resch is emblematic of the late medieval migration phenomena. He moved beyond political and language boundaries. He moved back and forth between different places. He brought new techniques and ideas with him, and we can even discover multiple affiliations. He was a citizen of Paris and a citizen of Basel even though he was born in neither of the two cities. In Paris he proudly demonstrated his connection with Basel, incorporating the Écu de Bâle into his own trademark. At the same time, he was well integrated into the wide network of printers and booksellers from the Rhine area in France. ${ }^{3}$ But he was also closely linked with French artisans, readers, intellectuals and institutions. Every step forward in his life cycle was accompanied by a geographical change. He moved for his education, his apprenticeship, to start his own business, and finally - for his retirement. Migration was nothing exceptional to Conrad Resch, it was an essential part of his life.

Conrad Resch's migration experience is representative of a large part of the society during the High and Late Middle ages. Popular perceptions of premodern, and especially medieval society, as somehow natural, pure and immobile are surprisingly persistent, and at the same time wrong. They reflect a general view of the Middle Ages as a form of otherworld, and mirror our modern society on which a certain set of positive or negative ideals is projected ${ }^{4}$. Migration is mainly recognized as the movement of whole ethnic groups, often in connection with war and the violent destruction of an existing order ${ }^{5}$. It can be exemplified by migration periods in the middle of the first millennium, Viking raids or the Crusades. The image of a generally immobile premodern society is even reflected by some of the most influential modern migration theorists. In Wilbur Zelinsky's well-known paper on the mobility transition, the "Premodern Traditional Society" is de-

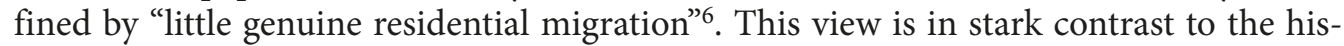
toriographical research of now almost a century. In fact, medieval society proved to be a highly mobile one. All layers of society were, in one way or another, in movement: from the constantly moving rulers, clerics, students, traders, artisans and peasants to beggars and vagrants without any fixed residence ${ }^{7}$.

Migration in the Middle Ages existed in many forms, reflecting the diversity of the society at the time. In the following article, I will focus on migration in urban centers

2 Febvre L., Martin H.-J. L’Apparition du livre. Paris, 1958. P. 445-447; Higman F. Lire et découvrir. La circulation des idées au temps de la Réforme. Genève, 1998. P. 25-26.

3 Armstrong E. Paris Printers in the Sixteenth Century: An international Society? // Printers and Readers in the Sixteenth Century / ed. by C. Coppens. Turnhout, 2005. P. 3-14.

${ }^{4}$ Oexle O.G. Die Wirklichkeit und das Wissen. Mittelalterforschung - Historische Kulturwissenschaft - Geschichte und Theorie der historischen Erkenntnis. Göttingen, 2011. P. 837-844.

${ }^{5}$ Often one sided views in this cases are critisized by Michael Borgolte in: Borgolte M. Migration als transkulturelle Verflechtungen im mittelalterlichen Europa. Ein neuer Pflug für alte Forschungsfelder // Historische Zeitschrift. 2009. T. 289. S. 261-285, here especially the chapter about the Germanic migration period. P. 271-276.

${ }^{6}$ Zelinsky W. The Hypothesis of the Mobility Transition // Geographical Review. 1971. Vol.61/2. P. 219-249, here especially p. 230. This view remains uncontested even in a recent reflection on Zelinsky's theory: Cooke Th. J. et al. A Prospective on Zelinsky's Hypothesis of the Mobility Transition // Geographical Review. 2018. Vol. 108, No. 4. P. 503-522.

7 Cluse Chr. Kommunale Zugehörigkeit und vielfältige Privilegien: Die Rechte Fremder im Hoch- und Spätmittelalter // Fremd und rechtlos? Zugehörigkeitsrechte Fremder von der Antike bis zur Gegenwart. Ein Handbuch / eds A. Coşkun, L. Raphael. Köln et al., 2014. P. 153-192, here pp. 157-159. 
in late medieval Europe. Cities depended heavily on the constant influx of people from outside its walls for population growth. At the same time, they were alluring places due to better economic opportunities, more personal freedom, a bigger marriage market, and many other reasons. The attraction of cities often extended far beyond the immediate vicinity, and they acted as crossroads of ideas and technologies. Conrad Resch was one such participant of this movement. In the following pages, I will try to highlight the importance of urban migration in medieval Europe. I will start by describing some of the demographic factors that led to the constant need of new people settling in towns. In the second part, I will give a number of examples from recent research, and also highlight the problems concerning getting the necessary information in the available sources and identifying huge parts of migrant population. Finally, I will attempt to describe some common characteristics that all these cases share.

First, we have to define who can be called a migrant, and who cannot. There existed a large number of different forms of geographic mobility. But mobility does not necessarily mean the same as migration. So who is a migrant and who is not? The modern understanding of migration as mainly transnational movement is not very helpful in the Middle Ages. Michael Borgolte defines migration as a lasting or at least long-term planned change of the place of living ${ }^{8}$. For Zelinsky, migration is "any permanent or semi-permanent change of residence" . At the same time, he highlights the importance of the connection between geographical and social mobility, while arguing that it is almost impossible to reach a consensus on what migration is precisely ${ }^{10}$. Regina Schäfer mentions that it is especially difficult to define the exact difference between mobility and migration in the case of rural-urban migration ${ }^{11}$. What exactly does planned changing of residence mean? When is an individual becoming a semi-permanent or permanent resident? People themselves often change their roles. Plans to migrate might not work out as expected. Re- and onward migration are common phenomena. Unexpected work opportunities, political pressure or simply love could convince people to stay in or move to places they had not considered before. Here, medieval forms of migration probably do not differ from modern ones. If we take another look at the life of our role model Conrad Resch, it is easy to understand the difficulties in finding an exact answer to the question of who a migrant is, and who is not. We do not know if he actually planned to stay in Paris for the rest of his life, or if it was only part of a specific cycle from the beginning onwards. He was constantly moving around, having no problem with assuming different identities and establishing affiliations. At the same time, he did not seem to be an outsider but was well integrated in the towns he moved to as well as in a broader artisan network. He maintained contact with the different places in which he had lived even after moving on, having business but probably also personal interests there. He was clearly a migrant from the perspective of the definitions at the beginning of this paragraph. His moves were planned in some ways, and they were at least semi-permanent changes of residence. Difficult though it is to find exact definitions of a migrant, it is still necessary to set some parameters to work with. In

${ }^{8}$ Borgolte M. Zur Einführung // Migrationen im Mittelalter. Ein Handbuch. Ed by Michael Borgolte. Berlin, 2014. P. 11-20, here p. 17.

9 Zelinsky W. The Hypothesis of the Mobility Transition. P.225.

10 Ibid. P. 223-224.

11 Schäfer R. Land-Stadt-Migration // Migrationen im Mittelalter. Ein Handbuch / Hrsg. M. Borgolte. Berlin, 2014. S. 311-318, hier S. 316-317. 
an urban context, I would state that a migrant must be born outside the city, cover some geographical distance ${ }^{12}$, and stay for a certain period of time in the place of arrival. Conrad Resch fulfills all of these requirements.

Medieval Europe was represented mainly by rural population. Urban population substantially varied between different regions. In Western Europe, between ten and fifteen percent of the population lived in urban centers ${ }^{13}$. In some areas, like Flanders or Northern Italy, it might have been up to forty percent of the population. The further eastwards we move, the lower the urban density became ${ }^{14}$. Of this, ten to fifteen percent, no more than half, lived in a number of cities with more than 10000 inhabitants $^{15}$. Even though cities were rather small and of limited importance in terms of population, they played a vital role in medieval society. They were centers of industrial production, they started to centralize political power, and they were melting pots for the medieval population. Individual freedom and opportunities for social mobility were in many cases higher there than in the countryside ${ }^{16}$.

At the same time, medieval cities were what Jacques Rossiaud described so drastically as the necropolis of the rural world ${ }^{17}$. They suffered from a constant negative growth rate. This was linked to a series of factors. First and foremost, mortality was high. In particular, the mortality of infants and children was higher than in the rural surroundings of medieval cities ${ }^{18}$. This was due to a number of reasons. Medieval towns were densely populated, with people often living in tiny apartments in close proximity to each other, making it easy for diseases to spread. Living conditions were often very bad. Humidity and a lack of fresh air might have challenged the immune systems of the urban population. The water was often polluted by urban industries, such as tanning or butchery. Sewerage systems rarely existed, and rubbish collection improved only in the course of time ${ }^{19}$. Even air pollution had already played a role owing to burning of coal and wood and treatment of animal

12 Even the notion of geographical distance can be questioned as done by Zelinsky: Zelinsky $W$. The Hypothesis of the Mobility Transition. P. 224.

${ }^{13}$ Le Mené M. Les temps difficiles (XIVe - XVe siècles) // Élisabeth Carpentier, Michel Le Mené, La France du XIe au XVe siècle. Population, société, économie. Paris, 1996. P.311-498, here pp.315-319.

${ }_{14}$ Schott D. Europäische Urbanisierung (1000-2000). Eine umwelthistorische Einführung. Cologne et al., 2014. P.53-56. Müller-Herrenschwand K. Brügges Bevölkerung und Wirtschaft zwischen 1282 und 1492 im Spiegel der Einbürgerungsquellen // Neubürger im späten Mittelalter. Migration und Austausch in der Städtelandschaft des alten Reiches (1250-1550). Zeitschrift für historische Forschung / Hrsg. R. Ch. Schwinges. Beiheft 30. Berlin, 2002. S. 479-506, hier S. 499. - For some lower numbers for Flanders see: Pounds N.J.G. Population and Settlement in the Low Countries and Northern France in the Later Middle Ages // Revue belge de philologie et d'histoire. 1971. T.49, No.2. P.369-402.

${ }^{15}$ Le Mené M. Les temps difficiles (XIVe - XVe siècles). P. 319.

${ }^{16}$ Carocci S. Social Mobility in the Middle Ages // Continuity and Change. 2011. T.26, No.3. P.367404.

17 Rossiaud J. Der Städter // Der Mensch des Mittelalters. Ed by Jacques Le Goff. Frankfurt, 1990. P. 156-197, here p. 157.

18 Woods R. Urban-Rural Mortality Differentials: An Unresolved Debate // Population and Development Review. 2003. T.29, No.1. P.29-46, here p.29. - For a detailed study on the mortality in the town of Vic in Catalonia see: Guilleré Chr. La mortalité de 1372 à 1407 // Population et démographie au Moyen Âge / ed. by O. Guyotjeannin. Paris, 1995. P. 119-144. - To get an impression on how people dealt with high child mortality and how it effected family structures, see: Journal d'un bourgeois de Paris sous François $1^{\text {er }} /$ ed. by J. Ph. Paris, 1963.

${ }^{19}$ For the case of Paris see: Favier J. Paris au XVe siècle. Nouvelle Histoire de Paris. Paris, 1974. P. 331332. 
remains had already. Townspeople were also more likely to become victims of violence ${ }^{20}$. Age, gender and wealth had an important influence on mortality. We have already mentioned high rates of infant and child mortality, but women and poor people were also in general more vulnerable. The danger of pregnancy and childbirth were probably higher for women in towns, where the system of support and protection that existed in the countryside was lacking. Even so, women were more likely to be part of the poorer groups of urban society and therefore sharing the fate of their male counterparts, comprising the most susceptible part of urban society ${ }^{21}$.

Mortality was not the sole cause for the negative growth of premodern cities. At the time of high mortality, birth rates were low. With average rates of around 1.5 children per woman, they were not far from fertility rates of $21^{\text {st }}$ century Europe ${ }^{22}$. Therefore, the size of the family remained rather small, with an average of only three people per family. In some cases and during certain periods, they could be even smaller ${ }^{23}$. Women in towns married later than in the countryside. Female migrants married even later than their native urban counterparts ${ }^{24}$. In addition to this, a large proportion of the urban population was single. While parts of this group consisted of the traditional singles of medieval society like clerics, students or widows, there also existed a considerable group of the society that simply never married. In a number of cases in England, singles comprised up to forty percent of urban tax payers ${ }^{25}$. Recognizing the fact that there were in general more women than men living in a town, we can assume that women also formed a majority of the urban single households ${ }^{26}$. All together, these factors kept the reproduction rate low, and in combination with the high mortality, created what we call today the urban graveyard effect. Even though this effect has been questioned in some cases in recent years, and the assumption of an "urban necropolis" seems too harsh today, there remains a consensus in historiography that premodern urban centers depended on immigration to grow or remain stable at least ${ }^{27}$.

Being a "death trap", as Kowaleski writes did not seem to keep people from moving to cities $^{28}$. In fact, evidence for certain places appears to prove quite the opposite. As Arlette

${ }^{20}$ Kowaleski M. Medieval People in Town and Country: New Perspectives from Demography and Bioarcheology // Speculum. 2014. T. 89, No. 3. P. 573-600, here pp. 589-592.

${ }^{21}$ Kowaleski M. Medieval People in Town and Country. P. 583-589; Farmer Sh. Down and Out Female in Thirteenth Century Paris // American Historical Review. 1998. T. 103, No. 2. P.345-372.

${ }^{22}$ Dubois H. La Dépression // Histoire de la population française. 1. - Des origines à la Renaissance / eds J. Dupâquier et al. Paris, 1988. P.313-366, here pp.347-353; Schäfer R. Land-Stadt-Migration. S.311312.

${ }^{23}$ Higounet-Nadal A. Les facteurs de la croissance de la ville de Périgeux auc Moyen Âge // Annales de Démographie Historique. 1982. P. 11-20, here p. 19; Russell J. C. Recent Advances in Medieval Demography // Speculum. 1965. T. 40, No.1. P. 84-101, here pp. 88-89.

${ }^{24}$ Kowaleski M. Medieval People in Town and Country. P. 586-587.

25 Ibid. P. 579-581.

${ }^{26}$ Jacobsen G. Female Migration and the late medieval town // Migration in der Feudalgesellschaft / Hrsg. G. Jaritz, A. Müller. Frankfurt, 1988. S. 43-55, hier S. 49; Kowaleski M. Medieval People in Town and Country. P. 579.

27 Two examples of studies challenging the urban graveyard effect: Sharlin A. Natural Decrease in Early Modern Cities. A Reconsideration // Past and Present. 1978. T. 79. P. 126-138; Woods, 2003. A. M.van der Woude questions the urban graveyard effect arguing that the native population could remain stable, but also criticizing Sharlin's conclusion as too radical: Van der Woude A. M. Population Developments in the Northern Netherlands (1500-1800) and the valdidity of the "urban graveyard" effect // Annales de Démographie Historique. 1982. P. 55-75.

${ }^{28}$ Kowaleski M. Medieval People in Town and Country. P. 593. 
Higounet-Nadal has shown in her impressive long-term study on the town of Périgeux in western France, a constant renewal of the urban population existed. There, on average, twenty percent of the family names mentioned in the tax lists were new every decade from the middle of the $14^{\text {th }}$ to the end of the $15^{\text {th }}$ century. At the same time, older names were likely to disappear a few decades after they had been first mentioned. A vast majority were only mentioned once, or appeared for less than twenty years. 95.14 percent spanned less than two generations, and only around three percent of the family names appeared throughout all the period of investigation ${ }^{29}$. While this might have been due to the specific characteristics of late medieval tax lists and a surprisingly high social mobility inside the urban population, these numbers still provide strong evidence for a constant renewal of the urban population through migration ${ }^{30}$.

So what were the reasons for the constant influx of newcomers in the cities of medieval Europe? Let's consider the example of Périgeux for a moment. Higounet-Nadal first mentions marriage as one of the main reasons. The marriage market in towns was bigger than in the countryside, and marrying into an urban family could be synonymous to rapid social ascent. This might have been especially true for artisans $s^{31}$. Other reasons she mentions are the demographic imbalance between rural and urban regions, economic growth in the city, a growing demand for workers, political and fiscal advantages and the difficulties of life in many parts of the countryside or in neighboring regions ${ }^{32}$. In some cases, towns even introduced strategical policies to attract migrants. Tax reductions were a common incentive to convince people to settle in a city. Sometimes, as in the case of Bruges, the fees for citizenship were flexibly adjusted, depending on the need to prevent or to promote immigration ${ }^{33}$. Better economic opportunities and more personal freedom were reasons for moving to urban centers. In particular, women could hope for a more independent lifestyle than in the countryside, even though their opportunities to control their own business diminished during the $15^{\text {th }}$ century ${ }^{34}$. Towns offered a bigger and more diverse market for artisans, as we can see in the case of Conrad Resch. Places like Basel and Paris were not only centers of book production, but also created a huge domestic market for them. Supplies of food and all kinds of different consumer products were better and more various than in the countryside. Education also played an important role. Students were a particularly urban phenomenon, but also a lot of apprentices, male and female, were sent to towns by their parents to receive skills in a trade. For young girls especially this was often a dangerous moment in their life, as examples from court registers from

${ }^{29}$ Higounet-Nadal A. Périgeux aux XIVe et XVe siècles. Étude de démographie historique. Bordeaux, 1978. P. 202-210.

30 Carocci S. Social Mobility in the Middle Ages; Higounet-Nadal A. Périgeux aux XIVe et XVe siècles. P. 211-219.

31 Higounet-Nadal A. Périgeux aux XIVe et XVe siècles. P. 254-255.

32 Ibid. P. 255-263.

${ }^{33}$ Müller-Herrenschwand K. Brügges Bevölkerung und Wirtschaft. S.487-491. - For the case of Bologna in the early $15^{\text {th }}$ century see: Guenzi A. L'immigration urbaine au XVe siècle: le cas de Bologne // Annales de Démographie Historique, 1982. P.33-42.

${ }^{34}$ On the important role of women in the Parisian silk and textile industry, see: Farmer Sh. The Silk Industries of Medieval Paris. Artisanal Migration, Technological Innovation, and Gendered Experience. Philadelphia, 2017. - On the diminishing of individual female working opportunities, see: Stabel P. Working Alone? Single Women in the Urban Economy of Late Medieval Flanders (Thirteenth - Early Fifteenth Centuries) // Single Life and the City. 1200-1900 / eds J. de Groot et al. London, 2015. P. 27-49. 
Paris and London indicate ${ }^{35}$. The assumption that country life was far more physically demanding than life in the city might be exaggerated, but it is true that the city offered a more diverse, exciting and probably joyful way of life ${ }^{36}$.

In many cases, the reasons an individual might have had for relocating to the city were mixed and probably less rational than they seem from our perspective today. It was not necessarily objective data that convinced people to move or to stay, but personal reflections. Migrants did not have full information about the places they could move to, but relied on the information they received from family members, friends, trading partners, or colleagues. In addition to such stories, poems, songs, theater pieces, and, from the late $15^{\text {th }}$ century onwards, even books played a role in creating a form of myth of the city that encouraged people to leave their home and move to a town. Here we can find a combination of economic and emotional factors playing an important role for all kinds of migrations ${ }^{37}$. The same might have been true for people moving from one town to another. As we have seen in the case of Conrad Resch, moving from one's birth place to a city is often only the first step in a long individual migration history. Also, territorial and social mobility were in close connection to each other. The hope for a better life and social ascent might have been one of the most important incentives for migrants in medieval times, and has been up until today. Towns were not necessarily the final destination for migrants, but in many cases also the point of departure. We have already spoken about the importance of re- and onward migration. Again, Conrad Resch can serve as a role model. Changing one place for another, staying there for a certain period of time and finally moving on, he is representative of a lot of artisan lives ${ }^{38}$. But cities could also quickly lose their attraction. When the economic and supply situation in a town was catastrophic, even a mass exodus could be possible ${ }^{39}$.

Where can we find evidence on migrants in medieval sources? First and foremost, medieval sources rarely give detailed and full information on urban immigrants. Newcomers to the city were hardly ever registered as such, and if they were, it was mostly only a certain proportion of them. Tax lists or lists of new citizens contained only the wealthier part of urban society. Even more mobile lower classes and marginal groups, such as vagrants, appeared only when they got in trouble with the urban authorities ${ }^{40}$. In order to

35 Registre Criminel du Châtelet de Paris. Du 6 Septembre 1389 au 18 Mai 1392, Volume I, edited by the Societé des Bibliophiles Français. Paris, 1861. P.41-47; Geremek B. Les Marginaux Parisiens aux XIVe et XVe siècles. Paris, 1976. P. 255-290; Rexroth F. Das Milieu der Nacht. Obrigkeit und Randgruppen im spätmittelalterlichen London. Göttingen, 1999. P. 294-296.

${ }^{36}$ Kowaleski M. Medieval People in Town and Country. P. 593-594.

37 Hoerder D. Cultures in Contact. World Migrations in the Second Millenium. Durham, 2002. P. 1621.

38 For some further examples, see: Geremek B. Les Marginaux Parisiens. P.308. - And the detailed description of the life of Dionysius Dreitwein, a furrier from Esslingen in Sout-West Germany in: Schulz K. Handwerkerwanderungen und Neubürger im Spätmittelalter // Neubürger im späten Mittelalter. Migration und Austausch in der Städtelandschaft des alten Reiches (1250-1550). Zeitschrift für historische Forschung / Hrsg. R. Ch. Schwinges. Beiheft 30. Berlin, 2002. S. 445-478, hier S. 463-476.

39 Higounette-Nadal A. La démographie des villes françaises au Moyen Âge // Annales démographique historique. 1980. P. 187-211, here pp. 206-208; Favier J. Paris au XVe siècle. P. 56-61. The "Bourgeois de Paris" mentions mass movements of people fleeing out of Paris in 1421: Journal d'un bourgeois de Paris de 1405 à 1449 / ed. by C. Beaune. Paris, 1990. P. 175-177.

${ }^{40}$ Quertier C. et al. Présentation // "Arriver“ en ville. Les migrants en milieu urbain au Moyen Âge / eds Cédric Quertier et. al. Paris, 2013. P.7-14, here pp. 8-9. 
form an opinion of what inquiries are possible to do, which types of sources can be helpful and which results we can be derived, I will give a short overview of some examples of research done on medieval urban migration in the last decades.

To get a quantitative impression of the number and origin of urban medieval migrants is a difficult task. Sources bearing broad demographic information are scarce, and immigrants were hardly ever indicated as such ${ }^{41}$. Still, there are a number of possibilities of obtaining at least a reliable impression on the importance of urban immigrants. One of the most promising methods to get information on medieval urban migrants is to examine names in the diverse fiscal documents of the time. While the origins of the people mentioned in these lists were hardly ever directly stated, their names can be revealing. Besides the names indicating the profession or relating to the physical appearance of their bearers, names indicating the place of origin were common. While the credibility of these place names was diminishing in the $15^{\text {th }}$ century, they represent a viable base of information as far as the previous two centuries are concerned. Unsurprisingly, these types of sources have been used extensively over the last decades. With regard to Paris, primary studies in this direction were already carried out in the 1930s by Karl Michaëlsson, who focused on the tax lists of the years between 1292 and 1313 . Between thirty and forty percent of the names mentioned in these lists are linked to the geographical origin of the bearer ${ }^{42}$. Similar researches have been done for a number of other places ${ }^{43}$. All of them point out a large number of people bearing names indicating migration background.

A different type of sources has a prominent role in the project on new citizens in towns in the Holy Roman Empire. Instead of relying on fiscal documents, this research group takes a look at the lists registering new Burghers. People gaining citizen rights were registered in these lists after paying the demanded fee. While these Bürgerbücher were widely spread in the Empire, not all of them contained the places of origin of newcomers. Still, no fewer than copies from 68 cities give reasonable indications for at least some period of time. They include more than 70000 new Burghers and 22000 geographical references $^{44}$. They also provide valuable information concerning the time when surnames were not indicative anymore. This vast amount of data enables not only to have an in-depth view on a particular migration area linked to one city, but also to make a comparison in a broader regional context. We see that different size of a city, economic emphasis, political situation and geographical location played an important role in the individual migratory strain leading to a particular place. While, for example, the south-western towns of Kon-

${ }^{41}$ Israel U. Fremde aus dem Norden. Transalpine Zuwanderer im spätmittelalterlichen Italien. Tübingen, 2005. P.26-34.

42 Michaëlsson $K$. Études sur les noms de personne français d'apres les rôles de taille parisien. Uppsala, 1927; Geremek B. Les Marginaux Parisiens. P. 304-305.

${ }^{43}$ For example, Périgeux: Higounette-Nadal A. Périgeux aux XIVe et XVe siècles. Blois: Morlet M.Th. Les noms de personnes à Blois et dans sa banlieu en 1389 // Population et démographie au Moyen Âge / ed. by O. Guyotjeannin. Paris, 1995. P.159-200. - Or England: McClure P. Patterns of Migration in the Late Middle Ages: The evidence of English Place-Name Surnames // The Economic History Review. 1979. Vol. 32, No. 2. P. 167-182.

44 Schwinges R. Chr. Eine Einführung über die Quellen // Neubürger im späten Mittelalter. Migration und Austausch in der Städtelandschaft des alten Reiches (1250-1550). Zeitschrift für historische Forschung / Hrsg. R. Ch. Schwinges. S. 17-52, hier S.30; Schwinges R. Chr. Die Herkunft der Neubürger: Migrationsräume im Reich des späten Mittelalters // Neubürger im späten Mittelalter. Migration und Austausch in der Städtelandschaft des alten Reiches (1250-1550). Zeitschrift für historische Forschung / Hrsg. R. Ch. Schwinges. S. 371-408, hier S. 371. 
stanz, Zurich or Ravensburg had a rather limited area of recruitment, the north-eastern port towns of Rostock, Stralsund and Danzig attracted newcomers with more diverse geographical origin ${ }^{45}$. Big cities, such as Cologne, Frankfurt or Strasbourg had not only a high potential for attracting migrants, but this potential was in many cases inclusive and did not overlap with other places ${ }^{46}$.

Fiscal documents as well as Bürgerbücher give certain indications about social and geographical characteristics of urban migrants. On average, one third of the people moving to a specific city came from the immediate vicinity of the town. One third covered a distance between forty and one hundred kilometers, and one third came from even more distant places of origin. ${ }^{47}$ It seems that there was a correlation between social status, specialization and the distance of migration, at least for artisans. The further people came from, the more they tended to have an urban background and a more specialized profession, and be wealthier and of higher status than immigrants from the direct surroundings of a city ${ }^{48}$. This would strengthen the argument that these migrants played an important role in the exchange of ideas and the transfer of new technologies ${ }^{49}$. Our role model Conrad Resch would easily fit in such a scheme.

While fiscal documents and Bürgerbücher give a certain amount of very valuable information, they are not without problems. First of all, they only represent a limited group of the urban society. To appear in these sources, people needed to be wealthy enough to pay taxes or have the financial and social capital to become citizens of a town. The Parisian tax lists mentioned above contained between 6000 and 15000 names representing one household each. Already the high fluctuation of households mentioned in the lists indicates their limited representativeness. The limitations are even more visible, when we compare them with the 61098 households listed in Paris in the Etat des paroisses et des feux from $1328^{50}$. Therefore, the households mentioned in the tax lists only represent between ten and twenty percent of the urban population. In addition, tax lists contain no information concerning the time and the reasons for people moving to the city. Furthermore, they leave us without any data about the stops that people might have taken between their place of origin and their destination, a common phenomenon as it is shown once more by the example of Conrad Resch ${ }^{51}$. The same is true for the lists of new Burghers. The overall majority of inhabitants of a city had neither the means nor interest in gaining citizenship. Even so, people who never actually lived in a town could still be citizens of this place. Often enough, people mentioned as newcomers gaining citizenship had already lived in them for years or even generation $s^{52}$. Last but not least, it is difficult to exactly link names containing a geographical reference to a certain place as many towns

45 Schwinges R. Chr. Die Herkunft der Neubürger. S. 378-384, 396-398.

46 Ibid. S. 388-393.

47 Ibid. S. 404-405; Higounette-Nadal A. Périgeux aux XIVe et XVe siècles. S. 219-236.

48 Farmer Sh. The Silk Industries of Medieval Paris. P.22-37; Hoerder D. Cultures in Contact. P. 83; Schulz K. Handwerkerwanderungen und Neubürger im Spätmittelalter. P. 448-458.

49 Koch B. Quare magnus artificius est: migrierende Berufsleute und Innovationsträger im späten Mittelalter // Neubürger im späten Mittelalter. Migration und Austausch in der Städtelandschaft des alten Reiches (1250-1550), Zeitschrift für historische Forschung. S. 409-444.

${ }^{50}$ Cazelles R. Paris à la fin du règne de Philippe Auguste à la mort de Charles V. 1223-1380. Paris, 1972. P. 132-137; Higounette-Nadal A. La croissance urbaine // Histoire de la population française. 1. — Des origines à la Renaissance / eds. J. Dupâquier et al. Paris, 1988. P. 267-312, here: pp. 305-307.

${ }^{51}$ Higounette-Nadal A. Périgeux aux XIVe et XVe siècles. P. 233.

52 Schwinges R. Chr. Einführung. P. 45-50. 
and villages had the same or similar names. Moreover, the variations in the writing style of place names in the sources do not facilitate the identification ${ }^{53}$. Large parts of the urban society remain therefore in the shadow, especially lower classes and particularly mobile groups who do not appear in this type of sources.

One way of overcoming the problems linked to tax lists or Bürgerbücher is to combine them with more qualitative sources that may allow a deeper insight into the migration history of certain individuals, which can be representative of others. One example of how this can be achieved is the work of Sharon Farmer on poor women in late $13^{\text {th }}$ century Paris. In addition to the already mentioned tax lists, the author reviews the inquests concerning the miracles at the tomb of Saint Louis recorded by Guillaume de Saint-Pathus in his Miracles de Saint Louis. These inquests not only state the name of the beneficiary of a miracle, but also their social status, where they come from and in many cases their whole life story. Also, they often provide detailed information about the witnesses. While the actual number of people appearing in this source is small, sixty-four miracles are mentioned in it, thirty-five of which pertaining to people living in Paris or its immediate surroundings. The level of details presented is impressive. We can gain comprehensive information about the lives, social networks and individual migration histories of people from the lower stratums of society. The overall majority of the people mentioned as living in Paris or its neighborhood, was born outside of the city. Many of them covered large distances, being born in Brittany or Normandy and finally ending up in Paris. We also learn a lot about family structures, the role networks of family and friends played in the individual migration decision, the frequency of onward and remigration, and the means of keeping contact with their places of origin ${ }^{54}$.

While the Miracles of Saint Louis give an impressive insight into medieval urban society, they remain a rather specific and singular source and cover only a rather short period of time. Another type of sources that offers information about lower layers of society is court registers. As far as the example of Paris is concerned, the criminal records of Chatelet from the late $14^{\text {th }}$ century are one prototype extensively studied in the last decades ${ }^{55}$. Another example would be letters of remission addressed to urban or royal authorities to gain freedom from punishment in a criminal case ${ }^{56}$. In some cases, they provide exact information on individual life and migration stories, and as they existed in a large number of different places all over Europe, a comparative approach can be taken. At the same time, the names of people, naturally, appeared in them only when something went wrong. Therefore, we are left with the negative sides of migration as the urban punitive apparatus tended to focus on the poor and mobile parts of society seen as a latent danger to the existing order. ${ }^{57}$ Notary acts, while also being part of the group of judicial sources, can widen the framework of court registers. They do not focus on criminality and misbehavior but on the social and economic relations between people. Even though they hardly ever mention migrants directly, they can give important hints, as we have already

${ }^{53}$ McClure P. Patterns of Migration.

54 Farmer Sh. Down and Out Female in Thirteenth Century Paris.

55 Geremek B. Les Marginaux Parisiens.

56 One example would be the case of Jean de Châtillon, who killed a picard textile worker in the streets of Paris, see: Lusignan S. Une affaire de mots et de couteaux: la mauvaise fortune d'un Picard à Paris // Un Moyen Âge pour aujourd'hui. Mélanges offert à Claude Gauvard / eds. J. Claustre et al. Paris, 2010. P. 119-127.

${ }^{57}$ Rexroth F. Das Milieu der Nacht. P. 293-332. 
seen in the case of Conrad Resch. Property, inheritances, business interests and family connections can give a significant indication of the geographic origin of the people concerned, as well as their migration route and networks in which they were integrated. At the same time, it is possible to gain an insight into a particular migration area of a specific city $^{58}$.

Another option is to concentrate on one specific group of urban immigrants. This is, in many cases, difficult as groups tended to mix up quickly within the urban population. Ethnic and religious separation of the cityscape, as we know from examples of towns in the Mediterranean and the Levant, was far less marked to north of the Alps, with some exceptions, such as Jews or Lombards ${ }^{59}$. Still, it is possible in some cases to focus on one specific group, like in the case of Flemish migrants in the English textile industry. Here, it is the comparison of sources in Flanders and in London that enables a deep insight in the fate of people. Fleeing political suppression and economic difficulties in Flanders in the middle of the $14^{\text {th }}$ century, many members of the leading textile producing families moved to England, and especially to London. Invited by the English king and tempted by a set of privileges, many of them settled there and brought along their knowledge about the textile production. Many of the Flemish stayed in contact with their families at home and remained integrated in an already existing trade and production network. Although tensions arose and finally culminated in the massacre of the Flemish community on 13 June 1381, this case is still indicative of how knowledge and technology transfer could work, which political measures could be taken to encourage migration, which problems could occur in the receiving communities, and how contrasting interests of different groups were in the urban environment ${ }^{60}$. The Flemish in London remained a rather distinct group still recognizable by their accent decades after ${ }^{61}$. However, they did not settle in one specific area but lived all over the city.

Recent advances in bioarcheology offer new opportunities for the examination of late medieval migration. The subfield of paleo demography, studying the human remains from medieval cemeteries, can supplement written sources. With these methods, researchers can identify the average age and the cause of death of those buried in the cemeteries. In addition to this, they can identify the nutrition and health issues that did not necessarily lead to death. Innovative approaches of analyzing the teeth of individual skeletons allow even tracking back regional and social origins ${ }^{62}$. While this new branch of research opens up new possibilities for understanding late medieval urban migration, it is not flawless. Human remains in the cemetery are not necessarily representative of the actual population of a town, and skeletons were often mixed from different periods as cemeteries had been in use over centuries. Rarely is the whole cemetery excavated, and many skeletons are in

58 For the case of Montpellier see: Reyerson K. L. Patterns of population attraction and mobility: the case of Montpellier, 1293-1348 // Society, Law, and Trade in medieval Montpellier / ed. by K. L. Reyerson. Alderschot, 1995. P. 257-281. - For a combination of all these types of sources in the case study of Treviso in northern Italy see: Scherman M. Trévise et ses migrants au XVe siècle // „Arriver“ en ville. Les migrants en milieu urbain au Moyen Âge / ed. by C. Quertier. Paris, 2013. P. 65-78.

59 Cluse Chr. Kommunale Zugehörigkeit und vielfältige Privilegien. P. 162-163.

${ }^{60}$ Lambert B., Pajic M. Immigration and the Common Profit: Native Cloth Workers, Flemish Exiles and Royal Policy in Fourteenth-Century London // Journal of British Studies. 2016. T. 55. P. 633-657.

${ }_{61}$ The inability to pronounce the shibboleth „Bread and Cheese“ was used to single out Flemings: Lambert B., Pajic M. Immigration and the Common Profit. P. 634.

62 Kowaleski M. Medieval People in Town and Country. P. 575-576, 596-597. 
such poor state that they cannot be further examined ${ }^{63}$. Furthermore, tracing the origin of certain skeletons requires a clear knowledge of the nutrition in a specific place at a specific time, which is not always available. Last but not least, the cost of such form of research is notably high. Despite certain limitations, the combination with more traditional forms of historical research can lead to a very fruitful cooperation and exciting new results ${ }^{64}$.

So which conclusions can we now draw from this short overview of some examples of research on late medieval urban migration? First of all, the demography of cities made constant influx of migrants from outside a necessity for urban growth and development. Without constant waves of newcomers, a premodern city was doomed to disappear. The renewal of the urban population enabled not only growth and prosperity, but also the transfer of new technologies and ideas. The urban environment offered opportunities for upward social mobility, even though not every individual migration history turned out to be a success story. Newcomers often remained vulnerable, and the danger to be pushed to the fringes of urban society was high. People often covered long distances during their individual migration history. The further people travelled, the more likely they were better educated, more specialized in a specific craft, and wealthier than their counterparts moving only within short distances from the surroundings to a town. Cities offered more economic and social opportunities. Individual freedom was often higher than in rural areas, wages better, the choice of available products bigger, and the walls offered security against the threats of premodern life. Even though a medieval town was not a particularly healthy environment, life was more comfortable, diverse, and probably joyful than in rural areas. The decision to move to a certain city remained an individual one, although existing connections with family and friends played an important role. Every city had its own migration area from which it recruited most of its new inhabitants. Re- and onward migration were common phenomena, and in many cases the step into a new life cycle was accompanied by a geographical change. While towns were in many cases rather open to newcomers, sometimes even directly promoting immigration, tensions between different groups were not uncommon and posed a threat to urban order.

Different types of medieval sources can give us valuable information about the quantity, the origin, the social situation and the fortune of urban migrants, but a lot of limitations remain, specifically with regard to lower classes of society, which are hard to identify. Still, a combination of different sources and methodologies can prove to be very fruitful. Studying migration can give us a deep insight into medieval society. Following Michael Borgolte, it is a total social phenomenon working as a key to understanding history ${ }^{65}$. Medieval societies were societies in movement, in contrast to popular images of the stable and immobile Middle Ages ${ }^{6}$. Migration played a crucial role for urban medieval centers. While some problems are inevitable, and migration in many cases is very difficult to be traced, medieval urban society cannot be understood without a detailed analysis of how

${ }^{63}$ Kowaleski M. Medieval People in Town and Country. P. 576.

64 One example would be the recent projects of Scandinavian historians and archeaologists on late medieval and early modern towns. See: Cornell P. et al. A Scandinavian Town and its Hinterland: The case of Nya Lödöse // International Journal of Historical Archeology. 2018. T. 22. P. 186-202.

65 Borgolte M. Zur Einführung. P. 20.

${ }^{66}$ Menjot $D$. Introduction. Les gens venus d'ailleurs dans les villes médievales: quelques acquis de la recherche, // „Arriver" en ville. Les migrants en milieu urbain au Moyen Âge / eds C. Quertier et al. Paris, 2013. P. 15-32, here p. 17. 
high the number of migrants was, how different their social and regional background was, and what their extent of integration and participation in the urban context was ${ }^{67}$. Let us have a final look at our role model Conrad Resch. His life was marked by migration, and he had a remarkable impact in the places he went to. He transferred ideas and technologies. He was able to integrate into different urban environments and different networks. After all, he was one of the people that formed a medieval city. Without the understanding of migration, it is impossible to understand the urban development in the late Middle Ages. Geographic mobility is one of the main characteristics of human society in all times and in all regions ${ }^{68}$, and the Middle Ages were no exception to this. Further research into this is necessary, which would be a valuable addition to medieval social history, and one of the keys to understanding the society in this period.

\section{References}

Armstrong E. Paris Printers in the Sixteenth Century: An international Society? Printers and Readers in the Sixteenth Century. Ed. by Ch. Coppens. Turnhout, Brepols Publ., 2005, pp. 3-14.

Borgolte M. Migration als transkulturelle Verflechtungen im mittelalterlichen Europa. Ein neuer Pflug für alte Forschungsfelder. Historische Zeitschrift, 2009, Bd. 289, S. 261-286.

Borgolte M. Zur Einführung. Migrationen im Mittelalter. Ein Handbuch. Hrsg. M. Borgolte. Berlin, De Gruyter Publ., 2014, S. 11-20.

Carocci S. Social Mobility in the Middle Ages. Continuity and Change, 2011, vol.26, no. 3, pp.367-404.

Cazelles R. Paris à la fin du règne de Philippe Auguste à la mort de Charles V.1223-1380. Paris, Hachette Publ., 1972, 470 p.

Cluse C. Kommunale Zugehörigkeit und vielfältige Privilegien: Die Rechte Fremder im Hoch- und Spätmittelalter. Fremd und rechtlos? Zugehörigkeitsrechte Fremder von der Antike bis zur Gegenwart. Ein Handbuch. Hrsg. A. Coşkun, R. Lutz. Köln, Böhlau Verlag, 2014, S. 153-192.

Cooke Th. J. et al. A Prospective on Zelinsky's Hypothesis of the Mobility Transition, Geographical Review, 2018, vol. 108, no. 4, pp. 503-522.

Cornell P. et al. A Scandinavian Town and its Hinterland: The case of Nya Lödöse. International Journal of Historical Archeology, 2018, vol. 22, pp. 186-202.

Coyecque E. Recueil d'actes notariés relatifs à l'histoire de Paris et de ses environs au XVIe siècle. T.I. 14981545. Paris, Imprimerie Nationale, 1905.

Dubois H. La Dépression. Histoire de la population française. 1. - Des origines à la Renaissance. Eds J. Dupâquier et al. Paris, Presse Universitaire de France, 1988, pp.313-366.

Farmer Sh. Down and Out Female in Thirteenth Century Paris. American Historical Review, 1998, vol. 103, no. 2, pp. 345-372.

Farmer Sh. The Silk Industries of Medieval Paris. Artisanal Migration, Technological Innovation, and Gendered Experience. Philadelphia, PENN - University of Pensylvania Press, 2017, 354 p.

Favier J. Paris au XVe siècle. Paris, Hachette Publ., 1974, 486 p.

Febvre L. M., Jean M. L’Apparition du livre. Paris, Michel Publ., 1958, 557 p.

Geremek B. Les Marginaux Parisiens aux XIVe et XVe siècles. Paris, Falmmarion Publ., 1976, 374 p.

Guenzi A. L'immigration urbaine au XVe siècle: le cas de Bologne. Annales de Démographie Historique, 1982, pp. 33-42.

Guilleré C. La mortalité de 1372 à 1407. Population et démographie au Moyen Âge. Ed. by O. Guyotjeannin. Paris, Éditions du CTHS, 1995, pp. 119-144.

Higman Fr. Lire et découvrir. La circulation des idées au temps de la reforme. Geneva, Droz Publ., 1998, 732 p.

Higounette-Nadal A. La croissance urbaine. Histoire de la population française. 1. - Des origines à la Renaissance. Eds J. Dupâquier et al. Paris, Presse Universitaire de France, 1988, pp. 267-312.

Higounette-Nadal A. La démographie des villes françaises au Moyen Âge. Annales démographique historique, 1980, pp. 187-211.

Higounet-Nadal A. Les facteurs de la croissance de la ville de Périgeux auc Moyen Âge. Annales de Démographie Historique, 1982, pp.11-20.

${ }^{67}$ Menjot D. Introduction. P. 17-21.

68 Borgolte M. Zur Einführung. P. 11. 
Higounet-Nadal A. Périgeux aux XIVe et XVe siècles. Étude de démographie historique. Bordeaux, Fédération Historique du Sud-Ouest, 1978, 458 p.

Hoerder D. Cultures in Contact. World Migrations in the Second Millenium. Durham, Duke University Press, $2002,779 \mathrm{p}$.

Israel U. Fremde aus dem Norden. Transalpine Zuwanderer im spätmittelalterlichen Italien. Tübingen, Niemeyer Publ., 2005, 380 p.

Jacobsen Gr. Female Migration and the late medieval town. Migration in der Feudalgesellschaft. Hrsg. G. Jaritz, A. Müller. Frankfurt, Campus Verlag, 1988, S. 43-55.

Koch Br. Quare magnus artificius est: migrierende Berufsleute und Innovationsträger im späten Mittelalter. Neubürger im späten Mittelalter. Migration und Austausch in der Städtelandschaft des alten Reiches (1250-1550). Zeitschrift für historische Forschung. Hrsg. R. Ch. Schwinges. Beiheft 30, Berlin, Duncker \& Humblot Publ., 2002, S. 409-444.

Kowaleski M. Medieval People in Town and Country: New Perspectives from Demography and Bioarcheology. Speculum, 2014, vol. 89, no. 3, pp. 573-600.

Lambert B. P. Milan, Immigration and the Common Profit: Native Cloth Workers, Flemish Exiles and Royal Policy in Fourteenth-Century London. Journal of British Studies, 2016, vol. 55, pp. 633-657.

Le Mené M. Les temps difficiles (XIVe - XVe siècles). Carpentier É., Le Mené M. La France du XIe au XVe siècle. Population, société, économie. Paris, Presses Universitaires de France, 1996, pp. 311-498.

Lusignan S. Une affaire de mots et de couteaux: la mauvaise fortune d'un Picard à Paris. Un Moyen Âge pour aujourd'hui. Mélanges offert à Claude Gauvard. Eds J. Claustre et al. Paris, Presses Universitaires de France, 2010, pp. 119-127.

McClure P. Patterns of Migration in the Late Middle Ages: The evidence of English Place-Name Surnames. The Economic History Review, 1979, vol. 32, no. 2, pp. 167-182.

Menjot D. Introduction. Les gens venus d'ailleurs dans les villes médievales: quelques acquis de la recherche. "Arriver" en ville. Les migrants en milieu urbain au Moyen Âge. Eds C. Quertier et al. Paris, Publications de la Sorbonne, 2013, pp. 15-32.

Michaëlsson K. Études sur les noms de personne français d’apres les rôles de taille parisien. Uppsala, Lundequistska Bokhandeln, 1927, 157 p.

Morlet M.-Th. Les noms de personnes à Blois et dans sa banlieu en 1389. Population et démographie au Moyen Âge. Ed. by O. Guyotjeannin. Paris, Éditions du CTHS, 1995, pp. 159-200.

Müller-Herrenschwand K. Brügges Bevölkerung und Wirtschaft zwischen 1282 und 1492 im Spiegel der Einbürgerungsquellen. Neubürger im späten Mittelalter. Migration und Austausch in der Städtelandschaft des alten Reiches (1250-1550). Zeitschrift für historische Forschung. Hrsg. R. Ch. Schwinges. Berlin, Duncker \& Humblot Publ., 2002, S. 479-506.

Oexle O.G. Die Wirklichkeit und das Wissen. Mittelalterforschung - Historische Kulturwissenschaft Geschichte und Theorie der historischen Erkenntnis. Göttingen, Vandenhoeck \& Ruprecht Publ., 2011, $1060 \mathrm{~S}$.

Pounds N. J. G. Population and Settlement in the Low Countries and Northern France in the Later Middle Ages. Revue belge de philologie et d'histoire, 1971, t. 49, no. 2, pp.369-402.

Quertier, Cédric et al. Présentation. „Arriver" en ville. Les migrants en milieu urbain au Moyen Âge. Eds C. Quertier et al. Paris, Publications de la Sorbonne, 2013, pp.7-14.

Rexroth Fr. Das Milieu der Nacht. Obrigkeit und Randgruppen im spätmittelalterlichen London. Göttingen, Vandenhoeck \& Ruprecht Publ., 1999, 450 S.

Reyerson K. L. Patterns of population attraction and mobility: the case of Montpellier, 1293-1348. Society, Law, and Trade in medieval Montpellier. Ed. by K.L. Reyerson. London, Varorium Reprints, 1995, pp. 257-281.

Rossiaud J. Der Städter. Der Mensch des Mittelalters. Hrsg. J.Le Goff. Frankfurt, Campus Verlag, 1990, S. 156-197.

Russell J. C. Recent Advances in Medieval Demography. Speculum, 1965, vol. 40, no. 1, pp. 84-101.

Schäfer R. Land-Stadt-Migration. Migrationen im Mittelalter. Ein Handbuch. Hrsg. M. Borgolte. Berlin, De Gruyter Publ., 2014, S.311-318.

Scherman M. Trévise et ses migrants au XVe siècle. "Arriver" en ville. Les migrants en milieu urbain au Moyen Âge. Ed. by C. Quertier. Paris, Publications de la Sorbonne, 2013, pp. 65-78.

Schott D. Europäische Urbanisierung (1000-2000). Eine umwelthistorische Einführung. Cologne et al., Böhlau Verlag, 2014, 395 S. 
Schulz K. Handwerkerwanderungen und Neubürger im Spätmittelalter. Neubürger im späten Mittelalter. Migration und Austausch in der Städtelandschaft des alten Reiches (1250-1550). Zeitschrift für historische Forschung. Hrsg. R. Ch. Schwinges. Berlin, Duncker \& Humblot Publ., 2002, S. 445-478.

Schwinges R.Ch. Eine Einführung über die Quellen. Neubürger im späten Mittelalter. Migration und Austausch in der Städtelandschaft des alten Reiches (1250-1550). Zeitschrift für historische Forschung. Hrsg. R. Ch. Schwinges. Berlin, Duncker \& Humblot Publ., 2002, S. 17-52.

Schwinges R.Ch. Die Herkunft der Neubürger: Migrationsräume im Reich des späten Mittelalters. Neubürger im späten Mittelalter. Migration und Austausch in der Städtelandschaft des alten Reiches (1250-1550). Zeitschrift für historische Forschung. Hrsg. R. Ch. Schwinges. Berlin, Duncker \& Humblot Publ., 2002, S. 371-408.

Sharlin A. Natural Decrease in Early Modern Cities. A Reconsideration. Past and Present, 1978, vol.79, pp. 126-138.

Stabel P. Working Alone? Single Women in the Urban Economy of Late Medieval Flanders (ThirteenthEarly Fifteenth Centuries). Single Life and the City, 1200-1900. Eds J. de Groot et al. London, Palgrave Macmillan Publ., 2015, pp. 27-49.

Woods R. Urban-Rural Mortality Differentials: An Unresolved Debate. Population and Development Review, 2003, vol.29, no. 1, pp. 29-46.

Van der Woude A. M. Population Developments in the Northern Netherlands (1500-1800) and the valdidity of the "urban graveyard" effect. Annales de Démographie Historique, 1982, pp.55-75.

Zelinsky W. The Hypothesis of the Mobility Transition, Geographical Review, 1971, vol.61, no. 2, pp. 219-249.

Статья поступила в редакцию 24 февраля 2019 г.

Рекомендована в печать 10 июня 2019 г.

Received: February 24, 2019

Accepted: June 10, 2019 